\title{
Evaluation of the Phytotoxic and Genotoxic Potential of Pulp and Paper Mill Effluent Using Vigna radiata and Allium cepa
}

\author{
Izharul Haq, ${ }^{1,2}$ Vineeta Kumari, ${ }^{1}$ Sharad Kumar, ${ }^{1}$ Abhay Raj, \\ Mohtashim Lohani, ${ }^{2}$ and Ram Naresh Bhargava ${ }^{3}$ \\ ${ }^{1}$ Environmental Microbiology Laboratory, Environmental Toxicology Group, CSIR-Indian Institute of \\ Toxicology Research (CSIR-IITR), Vishvigyan Bhavan 31, Mahatma Gandhi Marg, Lucknow, Uttar Pradesh 226001, India \\ ${ }^{2}$ Department of Biosciences, Integral University, Bas-ha Kursi Road, Dashauli, Lucknow, Uttar Pradesh 226026, India \\ ${ }^{3}$ Department of Environmental Microbiology, Babasaheb Bhimrao Ambedkar University (A Central University), \\ Vidya Vihar, Raebareli Road, Lucknow, Uttar Pradesh 226025, India
}

Correspondence should be addressed to Abhay Raj; araj@iitr.res.in

Received 22 April 2016; Accepted 11 August 2016

Academic Editor: Antimo Di Maro

Copyright (C) 2016 Izharul Haq et al. This is an open access article distributed under the Creative Commons Attribution License, which permits unrestricted use, distribution, and reproduction in any medium, provided the original work is properly cited.

\begin{abstract}
Pulp and paper mill effluent induced phytotoxicity and genotoxicity in mung bean (Vigna radiata L.) and root tip cells of onion (Allium cepa L.) were investigated. Physicochemical characteristics such as electrical conductivity (EC), biological oxygen demand $\left(\mathrm{BOD}_{5}\right)$, chemical oxygen demand $(\mathrm{COD})$, and total phenols of the pulp and paper mill effluent were beyond the permissible limit specified for the discharge of effluent in inland water bodies. Compared to control plants, seedling exposed to $100 \%$ effluent concentration showed a reduction in root and shoot length and biomass by $65 \%, 67 \%$, and $84 \%$, respectively, after 5 days of treatment. A. cepa root tip cells exposed to effluent concentrations ranging from 25 to $100 \% \mathrm{v} / \mathrm{v}$ showed a significant decrease in mitotic index (MI) from 32 to $11 \%$ with respect to control root tip cells $(69 \%)$ indicating effluent induced cytotoxicity. Further, the effluent induced DNA damage as evidenced by the presence of various chromosomal aberrations like stickiness, chromosome loss, anaphase bridge, c-mitosis, tripolar anaphase, vagrant chromosome, and telophase bridge and micronucleated and binucleated cell in A. cepa. Findings of the present study indicate that pulp and paper mill effluents may act as genotoxic and phytotoxic agents in plant model system.
\end{abstract}

\section{Introduction}

The pulp and paper mill uses large amounts of water and different chemicals during production processes of cellulose pulp from plant materials and produces large quantities of toxic and intensely coloured effluents. The effluents from pulping, bleaching, and washing processes are often characterized by their high colour, BOD, and COD and also consisting of potentially toxic chlorinated compounds, suspended solids, tannins, resin acids, and sulphur compounds along with lignins [1].

There are near about 759 pulp and paper mills in India and mostly using chlorine compounds in their bleaching sequences. The Indian pulp and paper industry is highly water intensive, consuming $100-250 \mathrm{~m}^{3}$ freshwater/ton paper and generating a corresponding $75-225 \mathrm{~m}^{3}$ wastewater/ton paper [2]. The effluents are often treated by biological treatment processes such as activated sludge process or aerated lagoon. However, compounds like lignin and chlorinated organic compounds are often not removed sufficiently by conventional methods due to their toxicity and low biodegradability and pose a threat to aquatic receiving environments [3].

Most of the Indian paper mills are small scale and do not have adequate treatment facilities. Thus, treated or allegedly treated wastewater from these mills contains toxic elements such as magnesium, sodium, chlorides, and sulphur as well as toxic organic compounds such as chlorinated lignins and phenolic derivatives, which can cause toxic 
effects on living organisms. In aquatic system, it blocks the photosynthesis and decreases the dissolved oxygen (DO) level, which adversely affects flora and fauna and causes toxicity to aquatic ecosystem $[4,5]$. In the contaminated soil it causes accumulation of toxic pollutants and metals. The chlorinated compounds are highly toxic and cause carcinogenic, mutagenic, clastogenic, and endocrinic effects [6].

Several studies confirm the toxic and genotoxic effects of pulp and paper mill effluents in living organisms. Most of this work has been carried out in Canada and Europe, but not enough data are available from Asia including India [7]. It is thus necessary to assess the toxic and genotoxic effects of effluents discharged by Indian pulp and paper mills.

The sensitivity of plants to different compounds can be used in toxicity tests to identify toxicants. Plant bioassays are well-established systems used for screening and monitoring of environmental pollutants. Phytotoxicity is the impact of various compounds or pollutants on seed germination and subsequent growth, while plant genotoxicity tests detect a wide range of genetic damage, including gene mutations and chromosomal aberrations [8].

In the present work, toxic and genotoxic effect of pulp and paper mill effluent was investigated on mung bean ( $V$. radiata L.) and onion (A. cepa L.), respectively. $V$. radiata is one of the important test species used to evaluate the phytotoxicity of environmental pollutants $[9,10]$. A. cepa $(2 n=16)$ is used for chemical screening and in situ monitoring of the genotoxicity of heavy metals, effluents, and herbicides [11-14].

\section{Materials and Methods}

2.1. Effluent Samples. Studies were conducted with effluents collected from the Star Paper Mill in Saharanpur, Uttar Pradesh (India). It is one of the large scale paper mills in India and is equipped with a Kraft pulping process and a three-stage bleaching process (chlorination, alkali extraction, and hypochlorination). It has a soda recovery plant which processes about $1700 \mathrm{~m}^{3} /$ day of black liquor from the pulping process. All wastewater from the mill is channeled through a single drain to the effluent treatment plant, where it is treated by activated sludge after primary physical treatment and finally released into the river Hindon through open drain. Effluent samples were collected monthly over a threemonth period (from February to April 2014). Samples were collected from effluent drain in plastic containers of 5 liters. All the samples were transported to the laboratory on ice. The samples were filtered with Whatman filter paper No. 1 and stored at $4^{\circ} \mathrm{C}$ until analysis.

2.2. Physicochemical Analysis. The effluent samples were analyzed for various physicochemical parameters (Table 1) according to APHA [15]. Colour unit (CU) and lignin content were estimated by established $[16,17]$ methods. The $\mathrm{pH}$ was measured with a digital $\mathrm{pH}$ meter (Metrohm, USA). Electrical conductivity (EC) was determined by a conductivity meter (Thermo Orion, model 162A, USA). Heavy metals were
TABLE 1: Physicochemical characteristics of pulp and paper mill effluent. Values are mean \pm SD of three samples.

\begin{tabular}{lcc}
\hline \multirow{2}{*}{ Parameters } & \multicolumn{2}{c}{ Values $(\mathrm{mg} / \mathrm{L})$} \\
& Effluent samples $(n=3)$ & Effluent standard* \\
\hline $\mathrm{pH}$ & $8.2 \pm 0.1$ & $5.5-9.0$ \\
$\mathrm{TDS}$ & $1080 \pm 54$ & 2100 \\
$\mathrm{EC}(\mu \mathrm{S} / \mathrm{cm})$ & $1640 \pm 82$ & 1000 \\
$\mathrm{BOD}$ & $165 \pm 8$ & 30 \\
$\mathrm{COD}$ & $384 \pm 19$ & 250 \\
Colour $(\mathrm{CU})$ & $1460 \pm 73$ & $\mathrm{NS}$ \\
Lignin & $249 \pm 12$ & $\mathrm{NS}$ \\
Total phenol & $44 \pm 2$ & 1.0 \\
Sulphate & $157 \pm 37$ & 1000 \\
Heavy metals & & \\
$\mathrm{Zn}$ & $0.051 \pm 0.00$ & 5.0 \\
$\mathrm{Fe}$ & $0.229 \pm 0.01$ & 3.0 \\
$\mathrm{Ni}$ & $0.02 \pm 0.00$ & 3.0 \\
$\mathrm{Mn}$ & $0.01 \pm 0.00$ & 2.0 \\
$\mathrm{Cu}$ & $0.006 \pm 0.0$ & 3.0 \\
$\mathrm{Cr}$ & $0.118 \pm 0.01$ & 2.0 \\
\hline
\end{tabular}

${ }^{*}$ Indian Standard Institute No. 2490 (1974); NS: not specified.

determined with an atomic absorption spectrometer (AAS) (GBC, Avanta Sigma, Australia).

2.3. Gas Chromatography-Mass Spectroscopy (GC-MS) Analysis. Effluent samples $(50 \mathrm{~mL})$ were acidified to $\mathrm{pH} 1-2$ using $1 \mathrm{~N} \mathrm{HCl}$ and then extracted thrice with an equal volume of ethyl acetate. The ethyl acetate extract was vacuum dried. The ethyl acetate extract was derivatized using trimethyl silyl (BSTFA (N, O-bis (trimethylsilyl) trifluoroacetamide) TMCS) [18]. An aliquot of $1 \mu \mathrm{L}$ of silylated compounds was injected in the injector port of a PE Autosystem XL gas chromatograph interfaced with a Turbomass mass spectrometric mass selective detector (Perkin Elmer, Waltham, MA, USA). The analytical column connected to the system was a PE-5MS capillary column $(20 \mathrm{~m} \times 0.18 \mathrm{~mm}$ internal diameter, $0.18 \mu \mathrm{m}$ film thickness). Helium gas with a flow rate of $1 \mathrm{~mL} / \mathrm{min}$ was used as the carrier gas. The column temperature program was $50^{\circ} \mathrm{C}$ for $5 \mathrm{~min}$ and then $50-300^{\circ} \mathrm{C}$ at $10^{\circ} \mathrm{C} / \mathrm{min}$, with a final hold time of $5 \mathrm{~min}$. The transfer line and ion source temperatures were maintained at 200 and $250^{\circ} \mathrm{C}$. A solvent delay of $3.0 \mathrm{~min}$ was selected. In the full-scan mode, electron ionization (EI) mass spectra in the range of 30-550 $(\mathrm{m} / \mathrm{z})$ were recorded at electron energy of $70 \mathrm{eV}$. Identification of compounds was done by comparing their mass spectra with those at the National Institute of Standards and Technology (NIST) library available with instrument.

2.4. V. radiata Phytotoxicity Test. $V$. radiata $\mathrm{L}$. Wilczek (var. K-851) was used in this study. Mung bean seeds were purchased from a local certified shop and surface-sterilized with $0.1 \%(\mathrm{w} / \mathrm{v}) \mathrm{HgCl}_{2}$ and then washed thrice with distilled water to remove all the traces of mercury. The seed germination test was conducted on filter paper in petri dishes 
$(20 \mathrm{~mm} \times 120 \mathrm{~mm})$ with two layers of filter paper $(125 \mathrm{~mm}$ in diameter, Whatman No. 1) followed by a layer of cotton on the bottom. Five test solutions $(12.5,25,50,75$, and $100 \%$ $\mathrm{v} / \mathrm{v}$ ) of the effluent were prepared using dechlorinated tap water. Each dish contained $10 \mathrm{~mL}$ of test solutions or tap water (control). Ten seeds were kept on filter paper in each petri dish soaked with the respective test solution. The plates were incubated at $28 \pm 1^{\circ} \mathrm{C}$ in the dark and the number of seeds germinated was observed after $48 \mathrm{~h}$. The experiment was conducted for three samples collected from different locations. After 5 days, five randomly selected seedlings were taken from each petri dish to measure root and shoot length. For biomass estimation, 10 seedlings from each petri dish were wrapped with aluminum foil and weighed the fresh weight first and then they were dried in oven at $70^{\circ} \mathrm{C}$ for $48 \mathrm{~h}$ and weighed the dry weight. Biomass was calculated by subtraction of dry weight from fresh and expressed in gram.

2.5. A. cepa Phytotoxicity Test. A. cepa phytotoxicity test was carried out as per the basic protocol [14] for the toxicity bioassay of the pulp and paper mill effluents. A. cepa bulbs used in this study were purchased from a local market. The test was conducted using healthy and equal-sized onion bulbs. Five onion bulbs were placed over $50 \mathrm{~mL}$ Falcon tubes filled with the different concentration of paper mill effluent $(25,50,75$, and $100 \% \mathrm{v} / \mathrm{v})$. Tubes were kept in an incubator at $23^{\circ} \mathrm{C}$ for 5 days. Dechlorinated tap water was used as control. The test solutions stored at $4^{\circ} \mathrm{C}$ were refilled morning and evening to ensure the contact between onion bulbs and samples present in the tube. After 5 days, the root length of onion bulbs at each concentration was measured. The experiment was conducted in five replicates of each dose for three samples collected from different locations. Inhibition in the growth of A. cepa roots was correlated with an index of the degree of toxicity [14].

2.6. Genotoxicity Test. Five onion bulbs per effluent concentration were initially rooted in tap water for $48 \mathrm{~h}$ as above until roots were $1-2 \mathrm{~cm}$ long and then transferred to test solutions for $24 \mathrm{~h}$, as a complete cell cycle of $A$. cepa root meristematic occurs within $24 \mathrm{~h}$ [19]. The root tips were fixed in absolute alcohol and glacial acetic acid (3:1) for $12 \mathrm{~h}$ and then washed a few times with distilled water. After this root tips were hydrolyzed with $1 \mathrm{~N} \mathrm{HCl}$ at $60-70^{\circ} \mathrm{C}$ for $5 \mathrm{~min}$ and washed with distilled water. This was followed by slide preparation using haemotoxylin as the stain [14, 19]. All the slides were analysed microscopically to calculate the mitotic index and the chromosomal aberrations present by the established procedure [20].

2.7. Data Analysis. Statistical analysis was performed using graph pad prism 5, version 5.1 (San Diego, California, USA). The data was analysed using one way analysis of variance (ANOVA) followed by Dunnett's multiple comparison test to confirm the variability of the data and validity of results. The criterion of significance was $p<0.05$. The values of experiments are reported as mean $\pm \mathrm{SD}(n=3)$.

\section{Results and Discussion}

3.1. Physicochemical Characteristics of Effluents. The measured physicochemical parameters of the effluent samples and ISI standard for tolerance limits of industrial wastewaters discharge into inland surface waters are given in Table 1 . The effluent $\mathrm{pH}$ was measured to be $\mathrm{pH}=8.2 \pm 0.1$ which is alkaline. It was within the tolerance limits. The average values of EC, BOD, COD, and phenols in the effluent were found to be significantly higher than the ISI standard [21]. EC which bears direct relation with the salinity and total salt content of the effluents was recorded as $1640 \pm 82 \mu \mathrm{S} / \mathrm{cm}$. The increased EC in irrigation water leads to lower crops production [22]. BOD which indicates the pollution strength of the waste waters was recorded as $165 \pm 8.25 \mathrm{mg} / \mathrm{L}$. High BOD is harmful to aquatic animals like fish and microorganisms [23]. The COD value of the effluent samples was recorded as $384 \pm$ $19.2 \mathrm{mg} / \mathrm{L}$. High COD levels indicate the toxic state of the waste water along with the presence of biologically resistant organic substances [24].

Further, effluents were found to be containing high level of colour unit $(1460 \pm 73 \mathrm{CU})$ and lignin $(249 \pm 12.4 \mathrm{mg} / \mathrm{L})$. Colour is usually the first contaminant to be recognized in wastewater/effluent that affects the aesthetics, water transparency, and gas solubility of water bodies. The colour of the effluent is mainly due to the presence of lignin and degradation products which are produced during different process stages such as pulping, bleaching, and alkali extraction [25]. Colour derived from lignin is an indicator of the presence of potentially inhibitory compounds and in addition may have direct inhibitory effects on some of the lower organisms in the food chain. The phenol content of the effluent was recorded as $44 \pm 2.2 \mathrm{mg} / \mathrm{L}$. Phenols are the major part of plant cell walls that are solubilized during industrial pulping and bleaching processes. Phenol and its derivatives induce genotoxic, carcinogenic, immunotoxic, hematological, and physiological effects in fish in receiving waters and have a high bioaccumulation rate along the food chain due to their lipophilicity [26]. The source of sulphate ions in effluent might be sodium sulphite, which is used during the pulping process [27]. Metals in the effluent might be due to their bioaccumulation by plants which are used as raw material as well as from various chemicals used during the paper making process. Pulp and paper mill effluent containing high colour, BOD, COD, and phenol has harmful effects on aquatic flora and fauna [28].

GC-MS is a powerful tool to identify compounds in wastewaters that has been used in a number of previous studies to identify compounds present in pulp and paper mill effluent $[29,30]$. The compounds detected by GCMS in ethyl acetate extracts of effluent are shown in Figure 1 and Table 2. The effluent was contaminated with hydrocarbons (3-octadecene $\mathrm{RT}=23.28$, 1 -octadecene $\mathrm{RT}=$ 26.62), phenolics ((+)-5-hydroxy-6-(1-hydroxyethyl)-2,7dimethoxynaphthoquinone, RT $=18.42)$, extractives $(\mathrm{D}$ fructose, 1,3,4,5,6-pentakis-o-(trimethyl silyl)-o,methyloxime RT $=24.53$, N-tetracosanol-1 RT $=32.13)$, and plantderived organic and fatty acids (Table 2 and Figure 1). GC-MS analysis indicates that treated effluent still contains various 
TABLE 2: Compounds identified in ethyl acetate extract from pulp and paper mill effluent sample as given in Figure 1.

\begin{tabular}{|c|c|}
\hline Retention time (in min) & Compounds \\
\hline 7.99 & Propanoic acid \\
\hline 12.82 & Phosphoric acid \\
\hline 18.42 & (+)-5-Hydroxy-6-(1-hydroxyethyl)-2,7-dimethoxynaphthoquinone \\
\hline 20.37 & Tartaric acid \\
\hline 23.28 & 3-Octadecene \\
\hline 24.53 & D-Fructose, 1,3,4,5,6-pentakis-o-(trimethyl silyl)-o,methyloxime \\
\hline 26.62 & 1-Octadecene \\
\hline 27.42 & Hexadecanoic acid \\
\hline 29.68 & 1-Heneicosanol \\
\hline 30.33 & Octadecanoic acid \\
\hline 32.13 & Tetracosanoic acid \\
\hline 34.07 & 1-Octacosanol \\
\hline 42.20 & $\alpha$-D-Galactopyranoside, methyl 2,3-bis-o-(trimethyl silyl )-, cyclic methylbronate \\
\hline 44.00 & $2^{\prime}-4^{\prime}-6^{\prime}-$ Trinitro-5 - phenyl-1,1 $1^{\prime}: 3^{\prime}, 1^{\prime \prime}$-terphenyl \\
\hline 48.88 & N,N'-Dicyclohexyl-1-cyano-7-pyrrolidinylperylene-3,4:9,10-tetracarboxylic acid \\
\hline
\end{tabular}

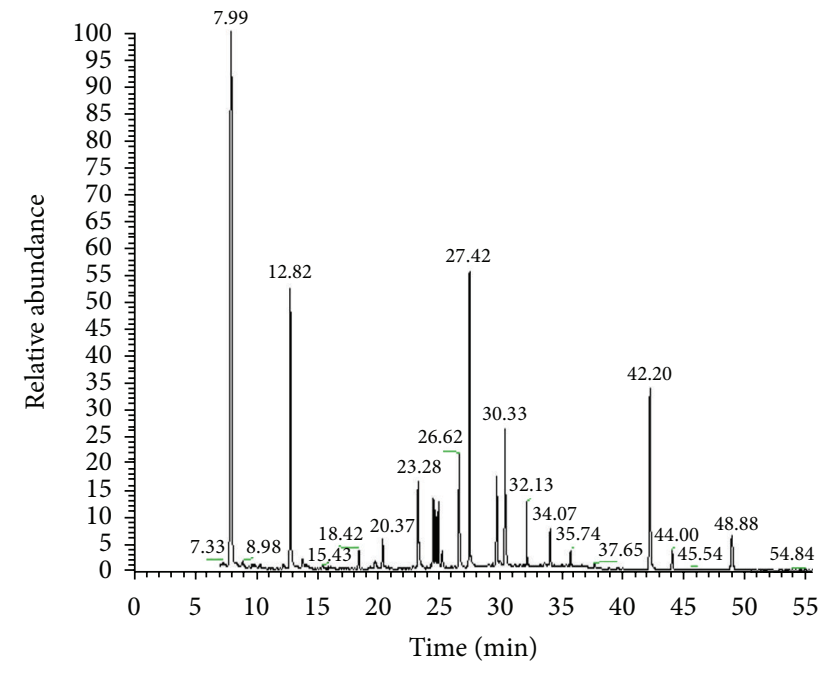

FIGURE 1: Typical chromatographic profile obtained by GC-MS of compounds extracted with ethyl acetate from pulp and paper mill effluent. MS-identified compounds with respect to their retention times are listed in Table 2.

persistent organic pollutants even after secondary biological treatment. The detected compounds had previously been reported in pulp and paper mill effluents and during lignin biodegradation [29-32].

3.2. Phytotoxicity Evaluation. Environmental toxicity assessment of industrial wastewater using a plant seed germination test is considered one of the simplest short-term methods [33]. Seed germination is a very sensitive process likely to be disturbed by inhibitory substances in the growing environment. In the present study mung bean seeds were germinated in different concentration of pulp and paper mill effluents and number of seeds germinated in each concentration was observed on $48 \mathrm{~h}$. The result indicates (Table 3 ) that no seed

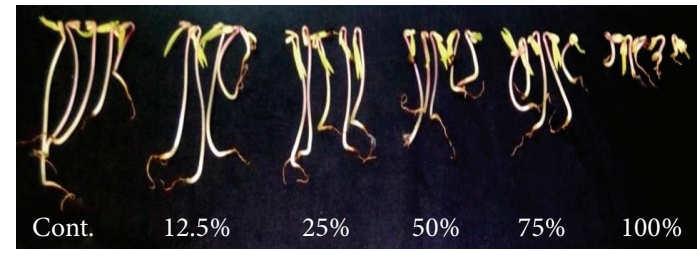

FIGURE 2: Effect of different concentrations of pulp and paper mill effluent on early seedling growth of mung bean.

germination inhibition was observed up to $50 \%$ (v/v) effluent concentration. Only 10 and 30\% seed germination inhibition was observed at 75 and $100 \%(\mathrm{v} / \mathrm{v})$ effluent concentrations, respectively. The result indicates that diluted effluents did not affect $V$. radiata seed germination significantly.

The effect of different concentration of effluent on early seeding growth (5 days) is apparent in Figure 2. Compared to controls, root lengths of 5-day-old seedling were highest at $12.5 \%(\mathrm{v} / \mathrm{v})$ effluent and then gradually decreased with increasing effluent concentrations (Table 3). Compared to controls, shoot lengths of seedlings were gradually decreased with increasing effluent concentrations. Significant reduction in root length $(65 \%)$ and shoot length (67\%) was observed at $100 \%(\mathrm{v} / \mathrm{v})$ effluent concentration. On the other hand, significant reduction in biomass $(68 \%)$ was observed at $12.5 \%$ $(\mathrm{v} / \mathrm{v})$ and this reduction was almost stable at 25 and $50 \%$ $(\mathrm{v} / \mathrm{v})$ effluent concentration. At $100 \%$ effluent concentration, there was an $84 \%$ reduction in biomass compared to controls. The significant reduction in root length, shoot length, and biomass of seedling at $100 \%$ effluent may be correlated with the cumulative effect of excess amount of EC, BOD, COD, and phenols in the effluent. This observation confirms the results obtained by others working on various crop plants [34-36].

Root growth inhibition of $A$. cepa root is considered a toxicity indicator since it may result from inhibition of the cell division [14, 37]. The effect of different concentrations 


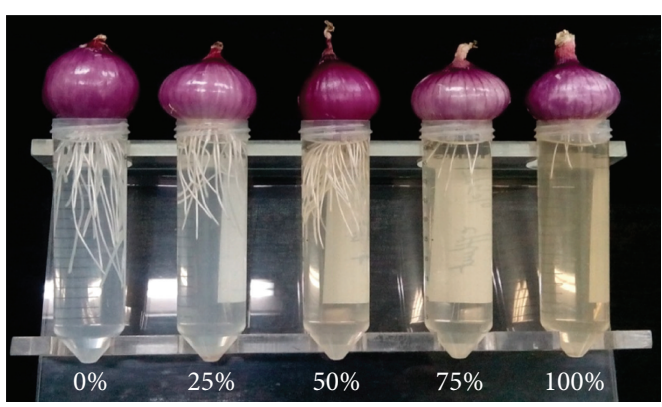

(a)

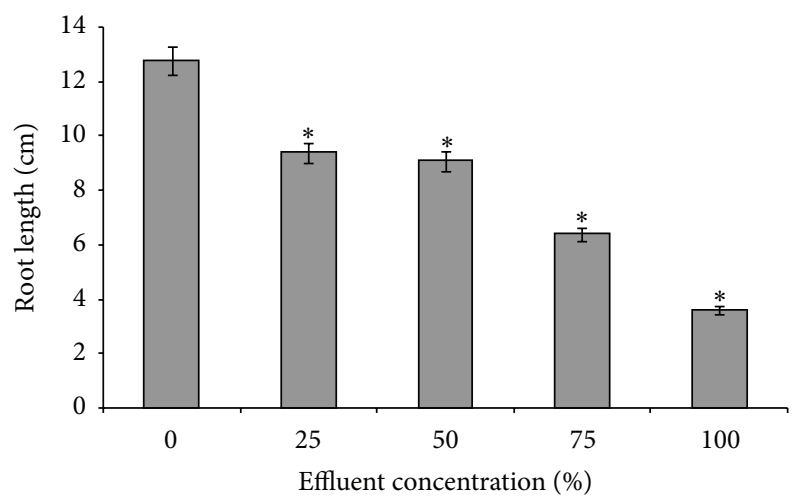

(b)

FIGURE 3: Root growth (a) and root length (b) of A. cepa after treatment with different concentrations of effluent. Values are mean \pm SD of three samples. ${ }^{*} p<0.05$, significant when compared to control using ANOVA.

TABLE 3: Effect of different concentrations of pulp and paper mill effluent on seed germination and root length, shoot length, and biomass of early seedling of mung bean plant.

\begin{tabular}{lcccc}
\hline Effluent (\%) & Germination $(\%)$ & Root length $(\mathrm{cm})$ & Shoot length $(\mathrm{cm})$ & Biomass $(\mathrm{gm})$ \\
\hline 0 & $100 \pm 0$ & $1.7 \pm 0.6$ & $5.1 \pm 1.4$ & $1.9 \pm 0.03$ \\
12.5 & $100 \pm 0$ & $1.9 \pm 0.2$ & $4.7 \pm 1.7$ & $0.6 \pm 0.07^{*}$ \\
25 & $100 \pm 0$ & $1.6 \pm 0.4$ & $4.3 \pm 1.1$ & $0.6 \pm 0.05^{*}$ \\
50 & $100 \pm 10$ & $1.4 \pm 0.2$ & $4.2 \pm 1.4$ & $0.6 \pm 0.03^{*}$ \\
75 & $90 \pm 10$ & $1.4 \pm 0.2$ & $4.1 \pm 1.4$ & $0.5 \pm 0.04^{*}$ \\
100 & $70 \pm 10$ & $0.6 \pm 0.3^{*}$ & $1.7 \pm 0.5^{*}$ & $0.3 \pm 0.03^{*}$ \\
\hline
\end{tabular}

Values are mean $\pm \mathrm{SD}$ of three samples. ${ }^{*} p<0.05$, significant when compared to control using ANOVA.

of pulp and paper mill effluent on the root growth and length of $A$. cepa is shown in Figures 3(a) and 3(b). Onions grown in pulp and paper mill effluent showed decreased root growth and root length when compared with controls. Root growth and root length inhibition was more pronounced at $75 \%$ and $100 \%(\mathrm{v} / \mathrm{v})$ effluent concentrations. Following 5 days of treatment, the mean root lengths were 3.9, 6.6, 9.0, 9.1 , and $11.8 \mathrm{~cm}$ when grown in $100 \%, 75 \%, 50 \%, 25 \%$, and $0 \%$, respectively (Table 4 ). Inhibition of $A$. cepa root growth and length observed in the present study following treatment with pulp and paper mill effluents was in agreement with the previous studies [12, 38].

3.3. Mitotic Index. Mitotic index (MI) is a good method in biomonitoring to assess the effect of number of pollutants on cell division [39]. MI measures the proportion of the cells in the mitotic phase of the cell cycle and its inhibition could be interpreted as cellular death [40]. The effect of pulp and paper mill effluent on percent MI in A. cepa is shown in Table 4 . The percentage of MI was lower than the control at all tested effluent concentrations and it decreased progressively with increasing effluent concentrations. This conforms well to the above-mentioned effects of effluent on root growth. Compared to a control value of 69 , mean MI (\%) values of $32,27,22$, and 11 were recorded for $25 \%, 50 \%, 75 \%$, and $100 \%$ effluent concentrations, respectively. The results indicate cytotoxic effect of the pollutants present in the pulp and paper mill effluent. These pollutants may interfere with the normal process of mitosis, thus preventing a number of cells from entering the prophase and blocking the mitosis cycle during interphase [41]. The inhibition of MI can also be attributed to be an effect of environmental chemicals on DNA/protein synthesis of the biological system [42, 43]. Declined MI following treatment with paper mill effluents have been reported in earlier studies $[38,41]$.

3.4. Chromosomal Aberrations. Chromosomal aberrations analysis in meristematic root tip cells of $A$. cepa is considered an efficient test to investigate the genotoxic potential of chemical agents, sewage, and industrial wastewaters [39, 44, 45]. Chromosomal aberrations are characterized by changes in either total number of chromosomes or chromosomal structure which can occur both spontaneously and as a result of the exposure to physical or chemical agents [46]. To evaluate the different chromosomal abnormalities, several types of chromosome aberrations are considered over the four stages of the cell cycle (prophase, metaphase, anaphase, and telophase). Chromosomal aberrations analysis not only allows estimation of genotoxic effects, but also enables evaluation of their clastogenic and aneugenic actions [20].

Chromosomal aberrations during mitotic stages in root tip cells of $A$. cepa following treatments are shown in Table 5 and Figures 4 and 5. No chromosomal aberrations and nuclear abnormalities were observed in control cells 
TABLE 4: Showing inhibition of root length and MI\% in root tip cells of A. cepa following treatment with different concentrations of pulp and paper mill effluents.

\begin{tabular}{lcccc}
\hline Concentration $(\%)$ & Root length $(\mathrm{cm})$ & Total cells & Dividing cells & MI\% \\
\hline 0 & $11.8 \pm 0.9$ & $540 \pm 20$ & $372 \pm 10$ & $69 \pm 0.9$ \\
25 & $9.1 \pm 0.6^{*}$ & $776 \pm 41$ & $244 \pm 12$ & $32 \pm 0.4^{*}$ \\
50 & $9.0 \pm 0.4^{*}$ & $775 \pm 36$ & $206 \pm 10$ & $27 \pm 0.5^{*}$ \\
75 & $6.6 \pm 0.5^{*}$ & $842 \pm 20$ & $186 \pm 8$ & $22 \pm 0.7^{*}$ \\
100 & $3.9 \pm 0.3^{*}$ & $801 \pm 20$ & $91 \pm 7$ & $11 \pm 0.5^{*}$ \\
\hline
\end{tabular}

Values are mean $\pm \mathrm{SD}$ of three samples. ${ }^{*} p<0.05$, significant when compared to control using ANOVA. MI was calculated as number of dividing cells $\times$ $100 /$ number of total observed cells.

TABLE 5: Frequency of chromosomal aberrations and nuclear abnormalities in root tip cells of $A$. cepa following treatments with different concentrations of pulp and paper mill effluents.

\begin{tabular}{|c|c|c|c|c|c|c|c|c|c|}
\hline \multirow{2}{*}{$\begin{array}{l}\text { Concentration } \\
(\%)\end{array}$} & \multicolumn{6}{|c|}{ Chromosomal aberrations } & \multicolumn{2}{|c|}{ Nuclear abnormalities } & \multirow{2}{*}{$\begin{array}{l}\text { Aberrant } \\
\text { cells (\%) }\end{array}$} \\
\hline & Stickiness & Bridge & Vagrant & Tripolar & Chromosomal break & c-metaphase & Binucleated cells & Micronuclei & \\
\hline 0 & $0.0 \pm 0.0$ & $0.0 \pm 0.0$ & $0.0 \pm 0.0$ & $0.0 \pm 0.0$ & $0.0 \pm 0.0$ & $0.0 \pm 0.0$ & $0.0 \pm 0.0$ & $0.0 \pm 0.0$ & $0.0 \pm 0.0$ \\
\hline 25 & $1.3 \pm 0.6$ & $2.0 \pm 1.0$ & $3.0 \pm 1.0$ & $2.0 \pm 1.0$ & $0.3 \pm 0.6$ & $4.0 \pm 1.0$ & $1.3 \pm 0.6$ & $0.0 \pm 0.0$ & $2.6 \pm 1.0^{*}$ \\
\hline 50 & $7.0 \pm 1.0$ & $9.0 \pm 1.0$ & $9.0 \pm 2.0$ & $2.7 \pm 1.2$ & $3.0 \pm 1.0$ & $14.3 \pm 2.1$ & $2.7 \pm 0.6$ & $1.3 \pm 0.6$ & $9.1 \pm 1.7^{*}$ \\
\hline 75 & $4.3 \pm 0.6$ & $3.0 \pm 1.0$ & $6.3 \pm 1.5$ & $1.3 \pm 0.6$ & $2.7 \pm 0.6$ & $13.0 \pm 2.0$ & $2.7 \pm 1.2$ & $2.3 \pm 0.6$ & $6.6 \pm 1.4^{*}$ \\
\hline 100 & $3.7 \pm 1.2$ & $4.7 \pm 1.5$ & $2.7 \pm 1.2$ & $3.0 \pm 1.0$ & $2.7 \pm 0.6$ & $13.3 \pm 1.5$ & $3.0 \pm 1.0$ & $1.7 \pm 0.6$ & $6.4 \pm 1.0^{*}$ \\
\hline
\end{tabular}

Values are mean \pm SD of three samples. ${ }^{*} p<0.05$, significant when compared to control using ANOVA. Chromosomal aberrations were scored on $100-500$ cells per slide.

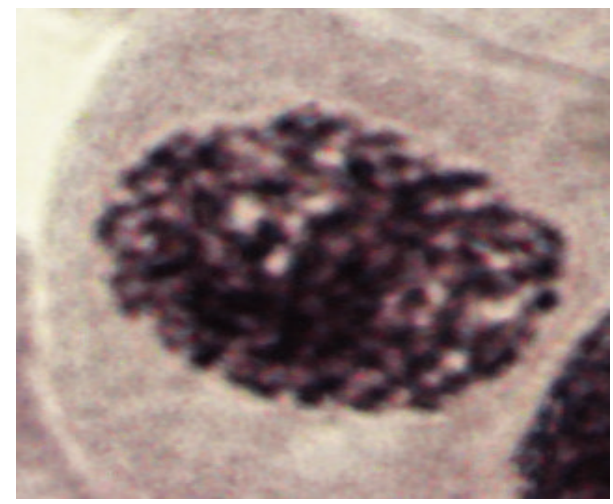

(a)

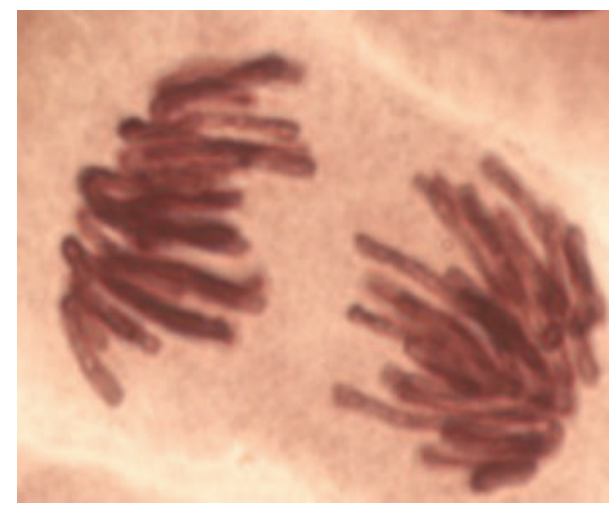

(c)

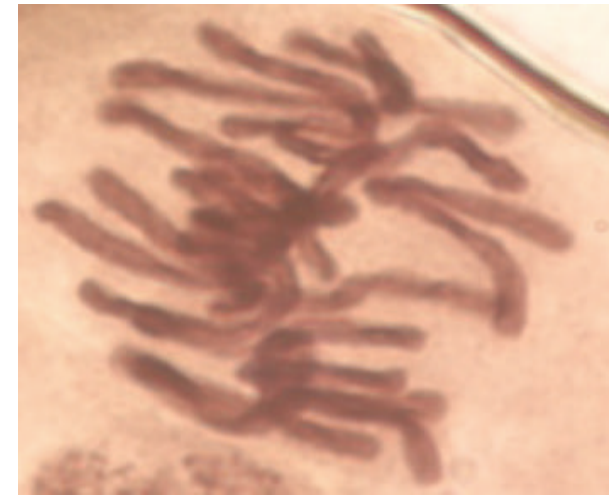

(b)

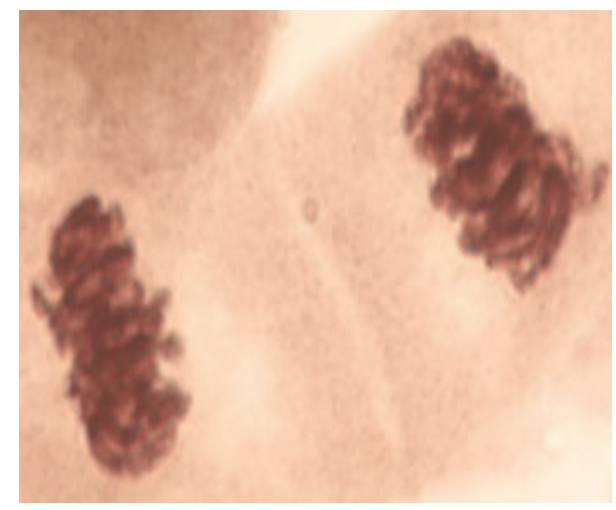

(d)

FIGURE 4: Various stages of mitosis show normal prophase (a), metaphase (b), anaphase (c), and telophase (d) in root tip cells of $A$. cepa treated with tap water (control). 


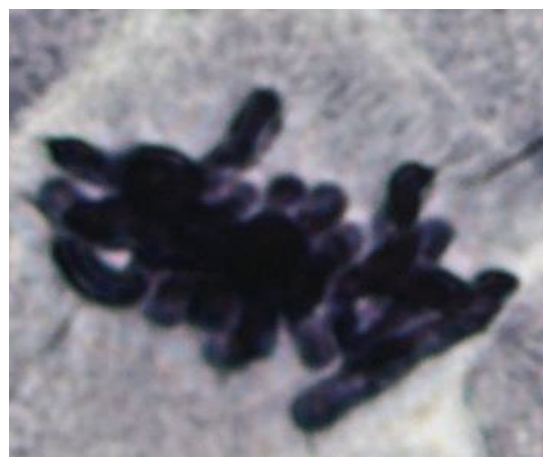

(a)

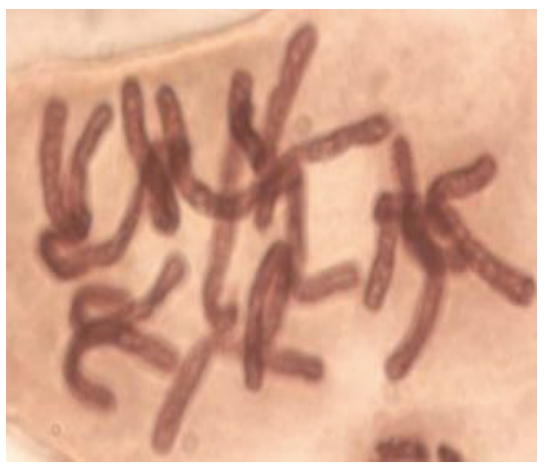

(d)

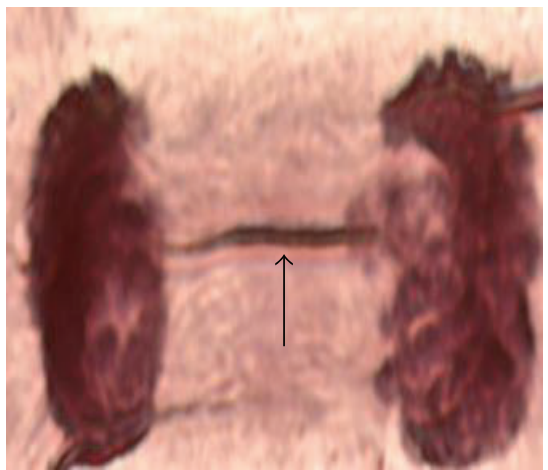

(g)

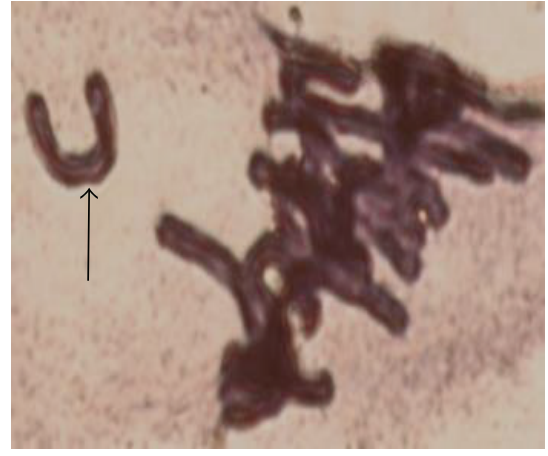

(b)

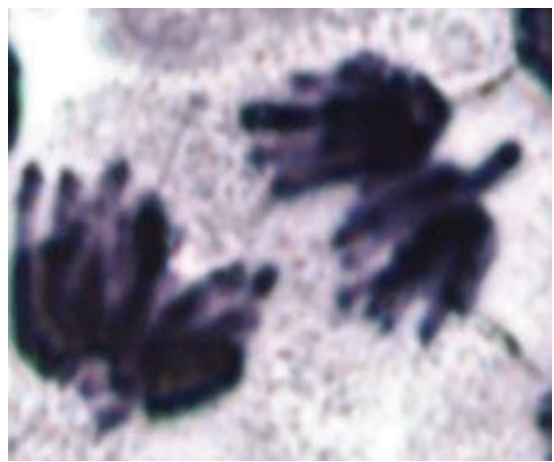

(e)

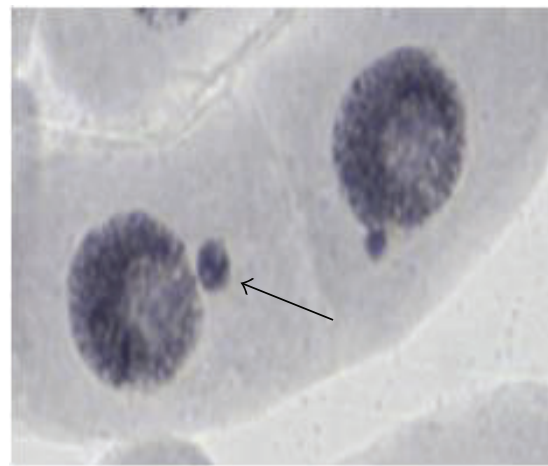

(h)

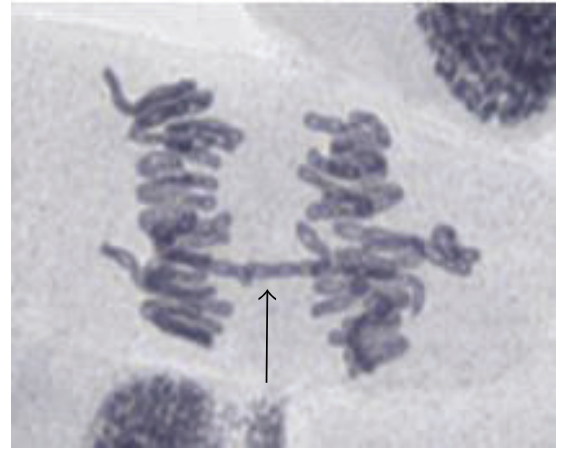

(c)

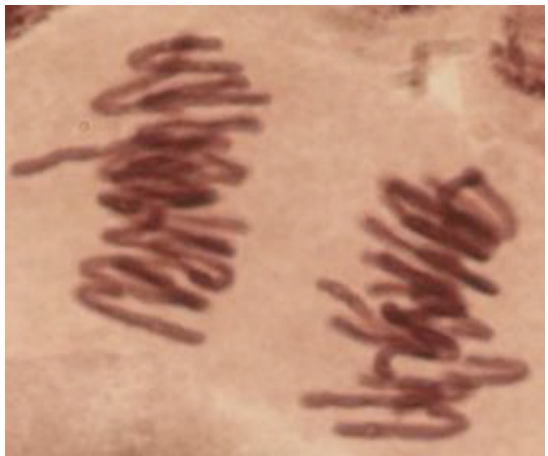

(f)

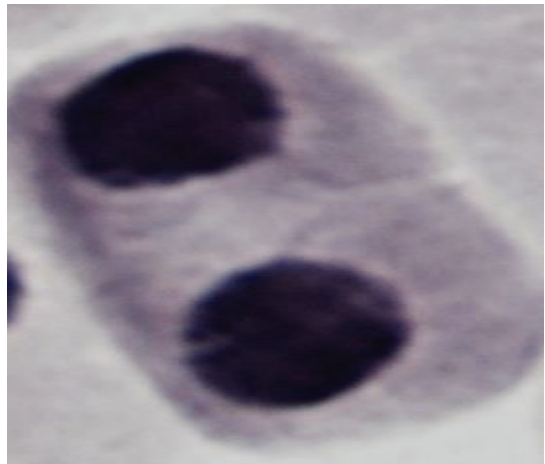

(i)

FIgURE 5: Chromosomal aberrations and nuclear irregularities observed in root tip cells of $A$. cepa following treatments with different concentrations of pulp and paper mill effluent. (a) Sticky metaphase, (b) chromosome loss, (c) anaphase bridge, (d) c-mitosis, (e) tripolar anaphase, (f) vagrant chromosome, (g) bridge at telophase, (h) micronucleated cell, and (i) binucleated cell.

treated with tap water (Figure 4). On the other hand, treatment with different concentrations of pulp and paper mill effluent induced significant chromosomal aberrations and nuclear abnormalities (Figure 5). All three effluents induced similar type of abnormalities. The observed aberrations were stickiness (Figure 5(a)), chromosome loss (Figure 5(b)), anaphase bridge (Figure 5(c)), c-mitosis (Figure $5(\mathrm{~d})$ ), tripolar anaphase (Figure 5(e)), vagrant chromosome (Figure 5(f)), and telophase bridge (Figure 5(g)). The nuclear abnormalities included micronucleated cell (Figure 5(h)) and binucleated cell (Figure 5(i)) in all treatments. The most frequent aberrations were c-mitosis, vagrant, and bridge chromosomes at all tested effluents concentration.
The percentage of aberrant cell was recorded highest at 50\% effluent concentration and thereafter declined. Induction of different types of chromosomal aberrations in A. cepa as a result of exposure to industrial wastewaters has been well documented [44, 45, 47].

Stickiness is considered a common sign of toxic effects on chromosomes probably leading to cell death [48]. Stickiness of chromosomes may occur due to either increased chromosomal contraction and condensation or depolymerization of DNA and partial dissolution of nucleoproteins $[49,50]$. Sticky chromosomes have been reported in A. cepa after treatment with industrial wastewaters, surface water, and heavy metals $[45,48,51]$. Chromosome bridges may be caused 
by stickiness of chromosomes preventing their complete separation during anaphase indicating a likely mutagenic event in the cell [52]. Colchicine mitosis (c-mitosis) is defined as an inactivation of the spindle followed by random scattering of the chromosomes around the cell. The effluent induced a high frequency of c-mitosis, which has been also shown by other studies [38,41], indicating that effluent is comparable in toxicity to colchicine. Occurrence of anaphase tripolar and chromosomal break indicates failure of the spindle apparatus to organize and function in a normal way [53].

Observation of nuclear abnormalities such as binucleated cells and micronuclei in A. cepa root tip cells is a clear indication of genotoxicity [54]. Binucleated cells may arise as a result of an incomplete process of cell division, that is, karyokinesis with incomplete cytokinesis. These cells also may arise due to the suppression of cell plate formation between cells in early telophase. Micronuclei are formed as a consequence of chromosome breakage (clastogenic agent) or whole chromosomes (aneugenic agent) that were not incorporated to the main nucleus during the cell division cycle [55]. Moreover, micronuclei also derive as processes of polyploidization, in which they originate from the elimination of exceeding DNA of the main nucleus in an attempt to restore the normal conditions of ploidy [56]. The induction of chromosomal aberrations and nuclear abnormalities in $A$. cepa root tip cells may be associated with the cumulative effect of various pollutants such as phenols, heavy metals, and other persistent organic pollutants detected in GC-MS. This result is similar to the previous findings in which roots of $A$. cepa exposed to pulp and paper mill effluents resulted in cells with chromosomal aberrations and nuclear abnormalities $[38,41]$.

\section{Conclusion}

Pulp and paper mill effluents were found to be containing higher EC, BOD, COD, and phenol along with various persistent organic pollutants. The effluents were phytotoxic, as they inhibited root length, shoot length, and biomass of $V$. radiata seedlings. Inhibition of $A$. cepa root growth and mitotic index were also observed following effluent treatments. The effluent induced DNA damage as evidenced by the presence of various chromosomal aberrations like stickiness, chromosome loss, anaphase bridge, c-mitosis, tripolar anaphase, vagrant chromosome and telophase bridge, micronucleated cell, and binucleated cell in root tip cells of A. cepa. From this study, presence of toxic and genotoxic agents in pulp and paper mill effluent after secondary treatment was proved. Thus, there is need for the adoption of proper treatment and bioremediation strategies to alleviate the pollution hazards caused by these wastewaters.

\section{Competing Interests}

The authors declare no competing interests.

\section{Acknowledgments}

Author Abhay Raj is thankful to Director, CSIR-Indian Institute of Toxicology Research (IITR), Lucknow (India), for his encouragement and support. The financial support of CSIR TASK FORCE project INDEPTH (BSC0111) is acknowledged. The present paper is CSIR-IITR paper number 3364.

\section{References}

[1] P. V. R. Subramanium, "Colour in pulp mill wastes and its removal, conversation of international association on water quality Nagpur India," pp. 25-29, 1976.

[2] P. K. Tewari, V. S. Batra, and M. Balakrishnan, "Efficient water use in industries: cases from the Indian agro-based pulp and paper mills," Journal of Environmental Management, vol. 90, no. 1, pp. 265-273, 2009.

[3] M. Ali and T. R. Sreekrishnan, "Aquatic toxicity from pulp and paper mill effluents: a review," Advances in Environmental Research, vol. 5, no. 2, pp. 175-196, 2001.

[4] A. Latorre, A. Malmqvist, S. Lacorte, T. Welander, and D. Barceló, "Evaluation of the treatment efficiencies of paper mill whitewaters in terms of organic composition and toxicity," Environmental Pollution, vol. 147, no. 3, pp. 648-655, 2007.

[5] D. T. Sponza, "Application of toxicity tests into discharges of the pulp-paper industry in Turkey," Ecotoxicology and Environmental Safety, vol. 54, no. 1, pp. 74-86, 2003.

[6] D. V. Savant, R. Abdul-Rahman, and D. R. Ranade, "Anaerobic degradation of adsorbable organic halides (AOX) from pulp and paper industry wastewater," Bioresource Technology, vol. 97, no. 9, pp. 1092-1104, 2006.

[7] S. Dey and S. Choudhury, "A review on toxicity of paper mill effluent on fish," Bulletin of Environment and Life Science, vol. 2, no. 3, pp. 17-23, 2013.

[8] J. Maluszynska and J. Juchimiuk, "Plant genotoxicity: a molecular cytogenetic approach in plant bioassays," Archives of Industrial Hygiene and Toxicology, vol. 56, no. 2, pp. 177-184, 2005.

[9] W. Wang and P. H. Keturi, "Comparative seed germination tests using ten plant species for toxicity assessment of a metal engraving effluent sample," Water, Air, and Soil Pollution, vol. 52, no. 3-4, pp. 369-376, 1990.

[10] A. Kannan and R. K. Upreti, "Influence of distillery effluent on germination and growth of mung bean (Vigna radiata) seeds," Journal of Hazardous Materials, vol. 153, no. 1-2, pp. 609-615, 2008.

[11] R. Liman, I. H. Ciğerci, and N. S. Öztürk, "Determination of genotoxic effects of Imazethapyr herbicide in Allium cepa root cells by mitotic activity, chromosome aberration, and comet assay," Pesticide Biochemistry and Physiology, vol. 118, pp. 38-42, 2015.

[12] O. Roa, M. C. Yeber, and W. Venegas, "Genotoxicity and toxicity evaluations of ECF cellulose bleaching effluents using the Allium cepa L. Test," Brazilian Journal of Biology, vol. 72, no. 3, pp. 471-477, 2012.

[13] S. M. Palacio, F. R. Espinoza-Quiñones, R. M. Galante et al., "Correlation between heavy metal ions (copper, zinc, lead) concentrations and root length of Allium cepa L. in polluted river water," Brazilian Archives of Biology and Technology, vol. 48, pp. 191-196, 2005.

[14] G. Fiskesjö, "The Allium test as a standard in environmental monitoring," Hereditas, vol. 102, no. 1, pp. 99-112, 1985. 
[15] APHA, Standard Methods for the Examination of Water and Wastewater, American Public Health Association, Washington, DC, USA, 21th edition, 2005.

[16] CPPA, Canadian Pulp and Paper Association Technical Section Standard Method H5P, CPPA, Montreal, Canada, 1974.

[17] I. A. Pearl and H. K. Benson, "The determination of lignin in sulphide pulping liquor," Paper Trade Journal, vol. 111, pp. 3536, 1940.

[18] K. Lundquist and T. K. Kirk, "Acid degradation of lignin. IV. Analysis of lignin acidolysis products by gas chromatography, using trimethylsilyl derivatives," Acta Chemica Scandinavica, vol. 25, no. 3, pp. 889-894, 1971.

[19] L. K. S. Chauhan, T. S. S. Dikshith, and V. Sundararaman, "Effect of deltamethrin on plant cells I. Cytological effects on the root meristems of Allium cepa," Mutation Research/Genetic Toxicology, vol. 171, no. 1, pp. 25-30, 1986.

[20] J. Rank, L. C. Lopez, M. H. Nielsen, and J. Moretton, "Genotoxicity of maleic hydrazide, acridine and DEHP in Allium cepa root cells performed by two different laboratories," Hereditas, vol. 136, no. 1, pp. 13-18, 2002.

[21] ISI (Indian Standard Institute), "Tolerance limits of industrial wastewater discharge into inland surface water," Tech. Rep. 2490, ISI, New Delhi, India, 1974.

[22] M. J. Edmund, "Understanding factors that affect $\mathrm{pH}$ and guide to alkalinity and pH control," Sea Scope Aquarium System, vol. 5, p. 35, 1998.

[23] P. Bajpai and P. K. Bajpai, "Biological colour removal of pulp and paper mill wastewaters," Journal of Biotechnology, vol. 33, no. 3, pp. 211-220, 1994.

[24] S. K. Dutta, "Study of the physico chemical properties of effluent of the paper mill that affected the paddy plants," Journal of Environmental Pollution, vol. 5, pp. 13-14, 2008.

[25] W. Yuxing and Y. Jian, "Decolorization of synthetic dyes and waste water from textile," Water Research, vol. 33, pp. 3512-3520, 1999.

[26] T. Tsutsui, N. Hayashi, H. Maizumi, J. Huff, and J. C. Barrett, "Benzene-, catechol-, hydroquinone- and phenol-induced cell transformation, gene mutations, chromosome aberrations, aneuploidy, sister chromatid exchanges and unscheduled DNA synthesis in Syrian hamster embryo cells," Mutation ResearchFundamental and Molecular Mechanisms of Mutagenesis, vol. 373, no. 1, pp. 113-123, 1997.

[27] A. Singhal and I. S. Thakur, "Decolourization and detoxification of pulp and paper mill effluent by Emericella nidulans var. nidulans," Journal of Hazardous Materials, vol. 171, no. 1-3, pp. 619-625, 2009.

[28] B. Karrasch, O. Parra, H. Cid, M. Mehrens, P. Pacheco, and R. Urrutia, "Effect of pulp and paper mill effluents on the microplankton and microbial self-purification capabilities of the Biobio river, Chile," Science of the Total Environment, vol. 359, no. 1-3, pp. 619-625, 2006.

[29] A. Raj, S. Kumar, I. Haq, and S. K. Singh, "Bioremediation and toxicity reduction in pulp and paper mill effluent by newly isolated ligninolytic Paenibacillus sp.," Ecological Engineering, vol. 71, pp. 355-362, 2014.

[30] I. Haq, S. Kumar, V. Kumari, S. K. Singh, and A. Raj, "Evaluation of bioremediation potentiality of ligninolytic Serratia liquefaciens for detoxification of pulp and paper mill effluent," Journal of Hazardous Materials, vol. 305, pp. 190-199, 2016.

[31] R. Chandra and R. Singh, "Decolourisation and detoxification of rayon grade pulp paper mill effluent by mixed bacterial culture isolated from pulp paper mill effluent polluted site," Biochemical Engineering Journal, vol. 61, pp. 49-58, 2012.

[32] A. Raj, M. M. K. Reddy, R. Chandra, H. J. Purohit, and A. Kapley, "Biodegradation of kraft-lignin by Bacillus sp. isolated from sludge of pulp and paper mill," Biodegradation, vol. 18, no. 6, pp. 783-792, 2007.

[33] W. Wang, "The use of plant seeds in toxicity tests of phenolic compounds," Environment International, vol. 11, no. 1, pp. 4955, 1985.

[34] U. J. Medhi, A. K. Talukdar, and S. Deka, "Impact of paper mill effluent on growth and development of certain agricultural crops," Journal of Environmental Biology, vol. 32, no. 2, pp. 185188, 2011.

[35] P. C. Mishra and S. Sahoo, Agro Potentiality of Paper Mill Wastewater in Soil Pollution and Soil Organisms, Ashish Publishing House, New Delhi, India, 1989.

[36] S. K. Dutta and C. L. Boissya, "Effect of paper mill effluent on germination of rice seed (Oryza sativa L. var Masuri) and growth behaviour of its seedlings," Journal of Industrial Pollution Control, vol. 12, no. 2, pp. 123-128, 1996.

[37] L. C. M. Egito, M. D. G. Medeiros, S. R. B. de Medeiros, and L. F. Agnez-Lima, "Cytotoxic and genotoxic potential of surface water from the Pitimbu river, northeastern/RN Brazil," Genetics and Molecular Biology, vol. 30, no. 2, pp. 435-441, 2007.

[38] R. Tipirdamaz, A. N. Gömürgen, D. Kolankaya, and M. Doğan, "Determination of toxicity of pulp-mill effluents by using Allium test," Tarim Bilimleri Dergisi, vol. 9, no. 1, pp. 93-97, 2003.

[39] D. M. Leme and M. A. Marin-Morales, "Allium cepa test in environmental monitoring: a review on its application," Mutation Research-Reviews in Mutation Research, vol. 682, no. 1, pp. 71-81, 2009.

[40] E. Rojas, L. A. Herrera, M. Sordo et al., "Mitotic index and cell proliferation kinetics for identification of antineoplastic activity," Anti-Cancer Drugs, vol. 4, no. 6, pp. 637-640, 1993.

[41] D. K. Shrivastava, "Cytotoxic effects of paper mill effluent on Allium cepa L," International Journal of Multdiciplinary Research and Developement, vol. 2, no. 2, pp. 657-661, 2015.

[42] S. Glińska, M. Bartczak, S. Oleksiak et al., "Effects of anthocyanin-rich extract from red cabbage leaves on meristematic cells of Allium cepa L. roots treated with heavy metals," Ecotoxicology and Environmental Safety, vol. 68, no. 3, pp. 343350, 2007.

[43] E. Rencuzogullari, A. Kayraldiz, H. B. Iia, T. Cakmak, and M. Topaktas, "The cytogenetic effects of sodiummetabisulphite, a food preservative in root tip cells of Allium cepa L," Turkish Journal of Biology, vol. 25, pp. 361-370, 2001.

[44] I. S. Grover and S. Kaur, "Genotoxicity of wastewater samples from sewage and industrial effluent detected by the Allium root anaphase aberration and micronucleus assays," Mutation Research, vol. 426, no. 2, pp. 183-188, 1999.

[45] S. Radić, D. Stipaničev, V. Vujčić, M. M. Rajčić, S. Širac, and B. Pevalek-Kozlina, "The evaluation of surface and wastewater genotoxicity using the Allium cepa test," Science of the Total Environment, vol. 408, no. 5, pp. 1228-1233, 2010.

[46] P. J. Russel, "Chromosomal mutation," in Genetics, B. Cummings, Ed., pp. 595-621, Pearson Education, San Francisco, Calif, USA, 2002.

[47] J. Rank and M. H. Nielsen, "Genotoxicity testing of wastewater sludge using the Allium cepa anaphase-telophase chromosome aberration assay," Mutation Research-Genetic Toxicology and Environmental Mutagenesis, vol. 418, no. 2-3, pp. 113-119, 1998. 
[48] G. Fiskesjö, "Allium test for screening chemicals; evaluation of cytological parameters," in Plants for Environmental Studies, W. Wang, J. W. Gorsuch, and J. S. Hughes, Eds., chapter 11, pp. 307333, CRC Press, Boca Raton, Fla, USA, 1997.

[49] I. Klasterska, A. T. Natarajan, and C. Ramel, "An interpretation of the origin of subchromatid aberrations and chromosome stickiness as a category of chromatid aberrations," Hereditas, vol. 83, no. 2, pp. 153-169, 1976.

[50] B. P. Kaufmann, M. R. McDonald, and M. H. Bernstein, "Cytochemical studies of changes induced in cellular materials by ionizing radiations," Annals of the New York Academy of Sciences, vol. 59, no. 4, pp. 553-566, 1955.

[51] O. B. Samuel, F. I. Osuala, and P. G. C. Odeigah, "Cytogenotoxicity evaluation of two industrial effluents using Allium cepa assay," African Journal of Environmental Science and Technology, vol. 4, no. 1, pp. 21-27, 2010.

[52] A. Z. El-Abidin Salam, E. H. A. Hussein, H. A. El-Itriby, W. A. Anwar, and S. A. Mansour, "The mutagenicity of Gramoxone (paraquat) on different eukaryotic systems," Mutation Research/Genetic Toxicology, vol. 319, no. 2, pp. 89-101, 1993.

[53] O. Aksoy, N. Ekici, and F. Dane, "Mitotic changes in root meristems of Lens culinaris treated with fusilade (fluazifop-pbutyl)," Asian Journal of Cell Biology, vol. 3, no. 1, pp. 34-40, 2008.

[54] S. Dash, K. K. Panda, and B. B. Panda, "Biomonitoring of low levels of mercurial derivatives in water and soil by Allium micronucleus assay," Mutation Research/Environmental Mutagenesis and Related Subjects, vol. 203, no. 1, pp. 11-21, 1988.

[55] D. M. Leme and M. A. Marin-Morales, "Chromosome aberration and micronucleus frequencies in Allium cepa cells exposed to petroleum polluted water-a case study," Mutation Research, vol. 650, no. 1, pp. 80-86, 2008.

[56] T. C. C. Fernandes, D. E. C. Mazzeo, and M. A. Marin-Morales, "Mechanism of micronuclei formation in polyploidizated cells of Allium cepa exposed to trifluralin herbicide," Pesticide Biochemistry and Physiology, vol. 88, no. 3, pp. 252-259, 2007. 

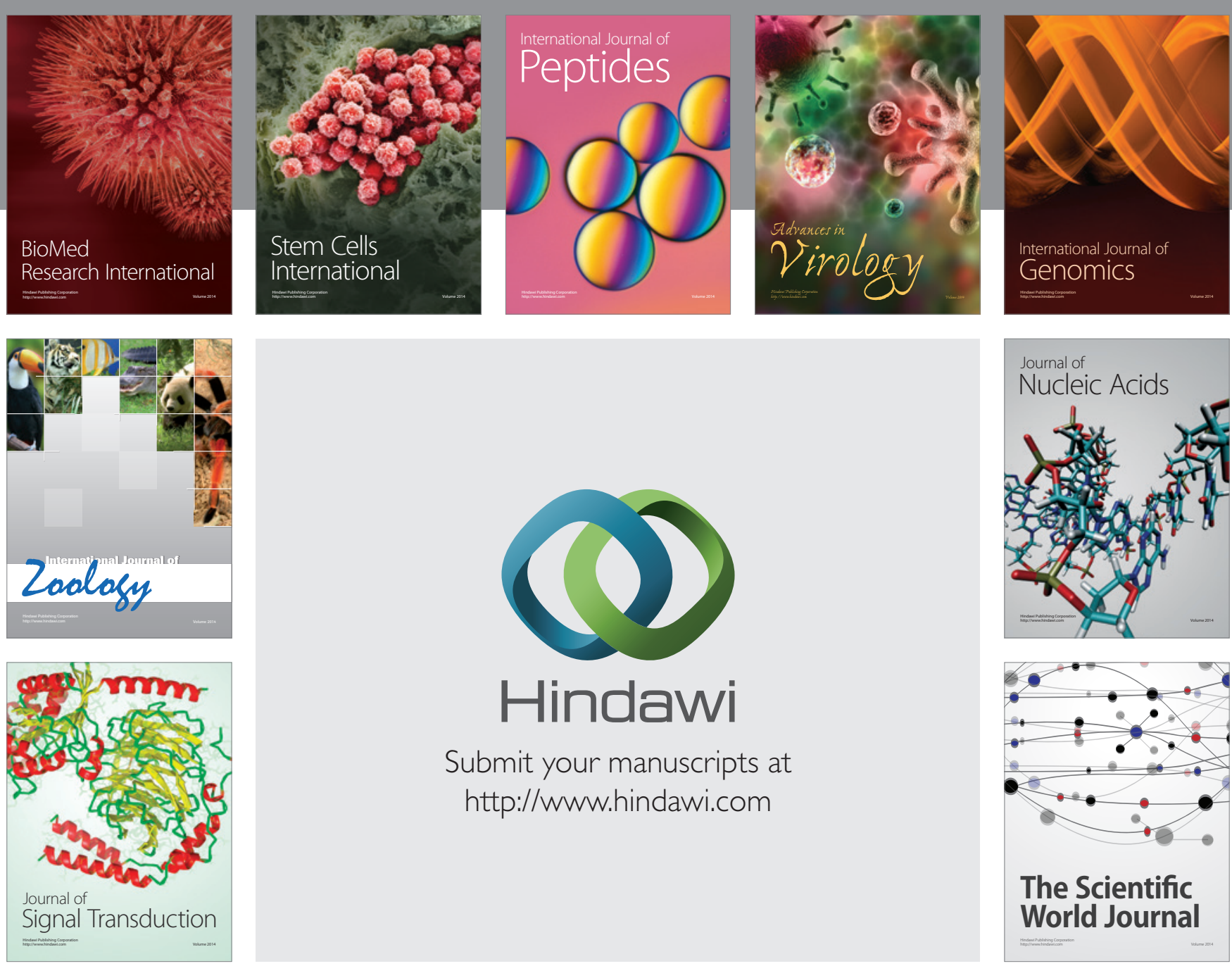

Submit your manuscripts at

http://www.hindawi.com
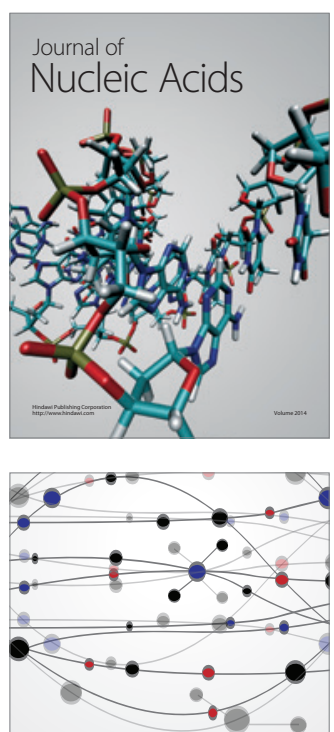

The Scientific World Journal
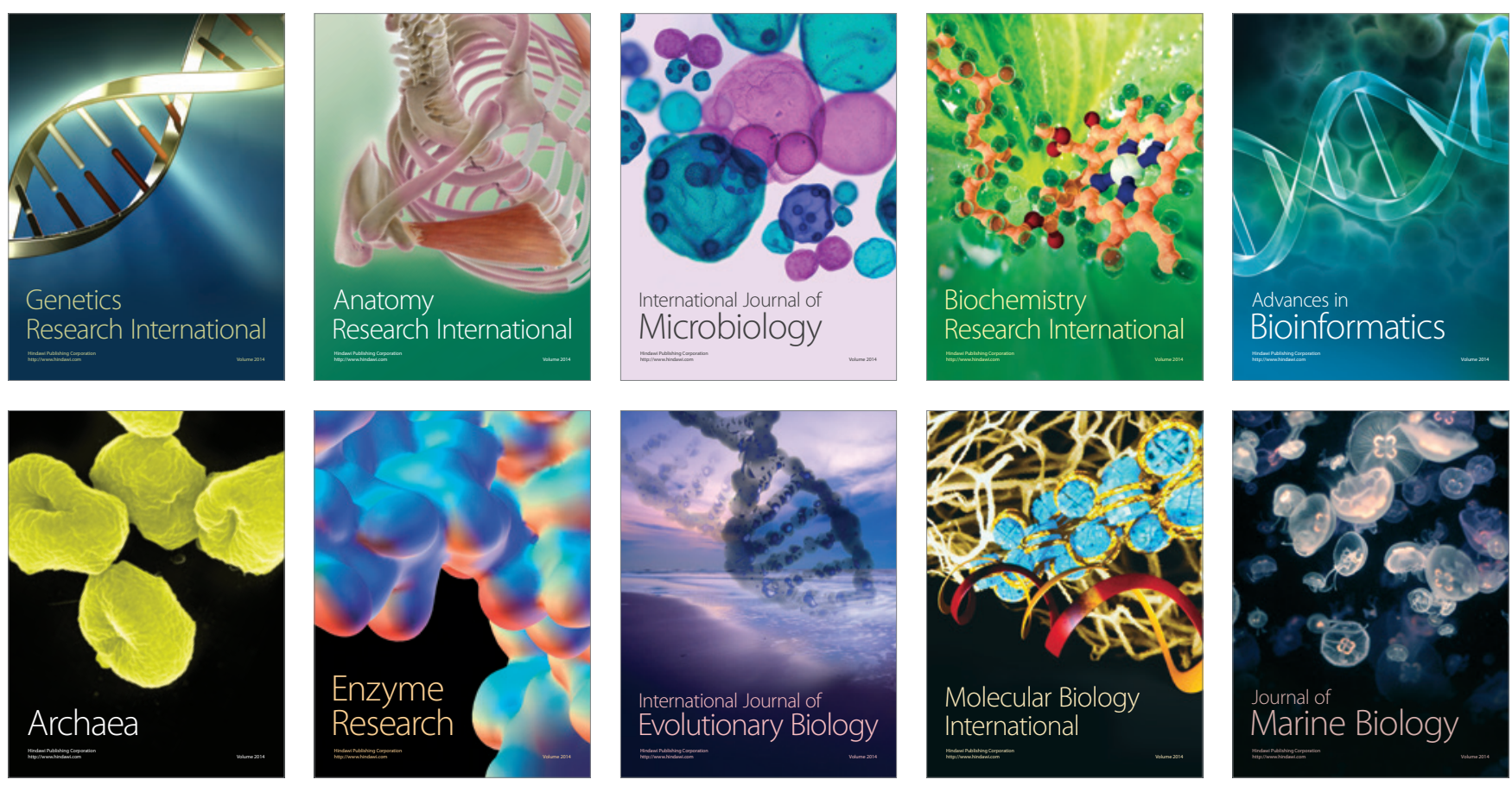